\title{
Maize Response to Different N Levels Following Different Preceding Crops
}

\author{
H.M. Ibrahim ${ }^{1}$, T.I.E. Abd El-Wahab ${ }^{2}$, A.I.Nawar ${ }^{1}$ and H.E. Khalii ${ }^{2}$
}

\begin{abstract}
Response of maize growth traits to different preceding crops was estimated at 105,120 and $135 \mathrm{kgN} /$ fed., during 2013 and 2014 summer seasons.

Preceding crops significantly affected maize grain yield and its attributes, i.e. number of grains/ ear, 100-grain and ear grain weights in addition to harvest index.

Maize gave maximum and minimum values of those traits after faba bean and sugar beet, producing lower estimates than those that contained faba bean.

Grain weight/ ear and grain yield/ fed., in addition to harvest index, significantly responded to $\mathrm{N}$ application levels, where their highest values were obtained from 135 $\mathrm{kgN} / \mathrm{fed}$.

Response of grain yield and harvest index to crop sequence $\times N$ level interaction effects were significant during the two seasons. Data indicated that $S_{6}$ sequence produced the greatest values of grain yield and harvest index with $135 \mathrm{kgN} / \mathrm{fed}$, while, the reverse occurred with the result of $S_{1}$ sequence $\times 105 \mathrm{kgN} /$ fed interaction. Interaction data, also, showed that $S_{6}$ and $S_{5}$ sequences, under $135 \mathrm{kgN} /$ fed were similar in their effects on both traits in the two seasons.

Data indicated the importance of relay cropping as a way to save time for a third or fourth crop growing.

Results of stepwise regression revealed that both 100grain weight and number of grains/ ear explained about $96 \%$ of the variation in grain yield in both seasons, indicating the importance of these two traits in determining productivity of maize. Also, factors affecting these two traits, such as $\mathbf{N}$ fertilization, might have an effect on grain yield production.
\end{abstract}

\section{INTRODUCTION}

Increasing food demand by mankind and fodder for livestock, with a decrease in suitable land area, motivated attention of agronomists to the intense use of land (Nawar et al., 2009). A more efficient use of resources is a major reason for the advantage of land use through multicropping in time dimension. Growing more than two crops per year, in a sequential form of crop intensification, requires a well crops choice and the best arrangement in crop sequences with suitable modifications in agricultural practices. Saving time through relay cropping, using short season crops and/ or harvesting crops in a green stage, enable farmers to achieve the intensification concept. Relay cropping of maize, with early maturing sunflower cultivars, will save time through the elimination of turnover period between successive crops. Responses of crop to its position in crop sequences were reported in several studies. Nawar (2004) showed that a gradual decay of residues, left after clover, established a continuous supply of nitrogen to the following growing crop. ELSodany and Abou-Elela (2012) and Shaalan et al. (2014) reported, in divergent studies, that legumes improved soil quality by increasing soil content from organic matter, and added that crop sequences of different rooting depths allowed crops to retrieve water and nutrients not accessed by their preceding crops. Khalil et al. (2004) supported these results and indicated that sunflower yield and its attributes (100and head seed weight) tended to be higher following legumes than non-legumes. Several investigators examined the effect of different previous crops on maize traits, including plant height and number of leaves/ plant (Nawar, 2004), number of grains and ear grain weight (Khalil et al., 2000), in addition to grain yield/ fed. (Nawar et al., 2009 and Shaalan et al., 2014) and, also, reported positive effects of preceding legume crops on studied traits.

Nitrogen controls biomass production through its effects on the number of leaves/ plant and leaf area generation, as well as, photosynthesis capacity (Zamski and Schoffer, 1996). The increase in $\mathrm{N}$ uptake, as $\mathrm{N}$ level increased, led to a greater size of vegetative shoot system, hence, larger photoassimilates translocation into seeds (Gardner et al., 1985). However, Fageria (2009) found that nitrogen was an important nutrient for plant vegetative and reproduction organs, which could be showed by a lack of nitrogen. On the other hand, Nawar et al. (2009) declared that optimum $\mathrm{N}$ level had been known to vary with soil type and its fertility, as affected by the previous crop. They showed a decrease in $\mathrm{N}$ level after legumes than after non-legumes. Several studies were conducted to investigate the effect of $\mathrm{N}$ supply on growth aspects of maize. Nawar (2004) reported that $\mathrm{N}$ supply to maize increased plant height, number of leaves/ plant and leaf expansion. However, Nawar (2004), Nawar et al. (2009) and Shaalan et al. (2014) attributed increases in maize grain yield to the increase in number of grains/ ear and single grain weight, as affected by increasing $\mathrm{N}$ levels.

\footnotetext{
${ }^{1}$ Crop Science Department, Faculty of Agricultural,

Alexandria University, Egypt.

${ }^{2}$ Crop Intensification Station, Field Crop Institute, A.R.C., Egypt.

Received July 26, 2015, Accepted August 27, 2015
} 
This investigation was conducted to determine the effect of relay cropping as a time saving factor for multiple cropping (triple sequential cropping) as a form for increasing productivity. It, also, aimed to examine the effect of winter crops, and relay cropped fodder maize, on the response of maize to applied nitrogen rates.

\section{MATERIALS AND METHODS}

Two field experiments were conducted at the Agricultural Research Station, Alexandria University, Egypt to investigate the effect of six forms of crop sequence on growth traits and yield of maize during 2012/ 2013 and 2013/2014 summer seasons. The six crop sequences, including maize as a terminal crop in each, are presented in Table (1).

Table 1. Maize crop sequences in both experiments

\begin{tabular}{ll}
\hline Sequence number & Sequence crops \\
\hline $1=\left(\mathrm{S}_{1}\right)$ & Su-fod-M \\
\hline $2=\left(\mathrm{S}_{2}\right)$ & Su-Sun-M \\
\hline $3=\left(\mathrm{S}_{3}\right)$ & Su---M \\
\hline $4=\left(\mathrm{S}_{4}\right)$ & Fa-fod-M \\
\hline $5=\left(\mathrm{S}_{5}\right)$ & Fa-Sun-M \\
\hline $6=\left(\mathrm{S}_{6}\right)$ & Fa----M \\
\hline $\begin{array}{l}\mathrm{Su}=\text { Sugar beet. } \\
\text { fod = fodder maize. }\end{array}$ & Sun = Sunflower. \\
$\mathrm{Fa}=$ Faba bean. & $\mathrm{M}=$ Grain maize.
\end{tabular}

In $\mathrm{S}_{1}$ and $\mathrm{S}_{4}$ systems, fodder maize was relay cropped, respectively, into sugar beet or faba bean and followed by maize, however, in $\mathrm{S}_{2}$ and $\mathrm{S}_{5}$, sunflower was relayed into sugar beet and faba bean, followed by maize, as a relay crop to sunflower. In $\mathrm{S}_{3}$ and $\mathrm{S}_{6}$, maize followed sugar beet or faba bean.

In addition, the effect of three $\mathrm{N}$ levels (i.e.: $\mathrm{N}_{1}=$ $105, \mathrm{~N}_{2}=120$ and $\mathrm{N}_{3}=135 \mathrm{kgN} /$ fed.), as ammonium nitrate $(33.5 \% \mathrm{~N})$, on maize traits were studied in both seasons.

A split-plot design, with three replicates, was used with the allocation of crop sequence and $\mathrm{N}$ levels, respectively, to the main and sub-plots. Each sub-plot comprised three wide ridges, each $3 \mathrm{~m}$ long and $1.2 \mathrm{~m}$ wide $\left(10.8 \mathrm{~m}^{2}\right.$ area $)$ in both seasons. Soil chemical analyses were $\mathrm{pH}=7.8$, total organic matter $=0.9 \%$ and $33.0,9.5$ and $588.0 \mathrm{ppm}$, respectively, for available $\mathrm{N}$, $\mathrm{P}$ and $\mathrm{K}$ as an average of the two seasons. Respective planting dates for crops, in the two experiments were October $15^{\text {th }}$ and $20^{\text {th }}$ (for sugar beet), November $15^{\text {th }}$ and $20^{\text {th }}$ (for faba bean), March $5^{\text {th }}$ and $10^{\text {th }}$ (for relay cropped fodder maize), March $15^{\text {th }}$ and $20^{\text {th }}$ (for relay cropped sunflower) and May $15^{\text {th }}$ and $20^{\text {th }}$ for maize relay and double cropping. Relay cropping of fodder maize and sunflower into faba bean and sugar beet and that of grain maize into sunflower plants were applied at the last irrigation of each sequence terminal crop. Sugar beet and faba bean were sown in hills on the upper side of ridges (with one plant/ hill) at intraspacings of 20 $\mathrm{cm}$. Respective cultivars for the crops were Beta Poly (sugar beet), Giza 716 (faba bean), Giza 102 (sunflower) and Giza 310 (3-way cross, maize). Household maize seeds were planted as a source of fodder maize in the two experiments. Nitrogen was applied in two equal doses, at the first and second irrigations of maize. Other cultural practices were applied as recommended for maize and other crops included in the different sequences.

At harvest, a random sample of ten plants were taken from each experimental unit to measure the following traits: plant and ear heights $(\mathrm{cm})$, number of leaves/ plant, ear leaf area $\left(\mathrm{cm}^{2}\right)$, No. of grain weight/ ear and harvest index (HI). The average weight of five random 100-grain weight samples, from each treatment, was calculated as a record of 100-grain weight. Grain yield $(\mathrm{kg})$ was determined from the inner ridge in each sub-plot, then, converted to ardab/ fed. (one feddan = 0.42 ha and one ardab $=140 \mathrm{~kg}$ grains).

Statistical analysis included the analysis of variance and stepwise regression for the studied traits and was applied, according to Gomez and Gomez (1984).

\section{RESULTS AND DISCUSSION}

\section{A- Effect of preceding crops on maize traits:}

Means of the studied characters, as affected by the preceding crops, are presented in Tables (2 and 3). Data showed significant or insignificant responses of maize traits to such crops in both seasons. Differences in ear leaf area, among the six crop sequences, were significant in both seasons. Faba bean $\left(\mathrm{S}_{6}\right)$ resulted in the highest significant ear leaf area, compared to those obtained from the other crop sequences, except for $\mathrm{S}_{5}$ sequence. These results might be attributed to the more availability of soil $\mathrm{N}$, with respect to $\mathrm{S}_{6}$ (faba bean) and $\mathrm{S}_{5}$ (maize relay cropping to sunflower grown after faba bean), leading to higher $\mathrm{N}$ uptake, consequently, to increases in ear leaf expansion (Nawar, 2004). The negative results in sugar beet sequences $\left(\mathrm{S}_{1}, \mathrm{~S}_{2}\right.$ and $\left.\mathrm{S}_{3}\right)$ might be attributed to the longer growth duration of sugar beet with greater depletion of soil N, hence, lower $\mathrm{N}$ availability and uptake that was associated with a decline in maize ear leaf area. Meanwhile, reductions in such trait, after fodder maize in $\mathrm{S}_{4}$, could be attributed to the soil supply with lower organic $\mathrm{N}$ and greater $\mathrm{N}$ uptake from the top soil by the preceding fodder maize. Khalil et al. (2004), Nawar (2004) and Khalil et al. (2011) reported that maize, following faba bean had greater ear leaf area, compared to maize after non legumes, as a result of greater $\mathrm{N}$ availability and uptake, hence, an increase in leaf expansion. 
There were significant variations in number of grains/ ear among all preceding crops. Faba bean crop sequences produced greater number of grains/ ear, compared to the respective treatments of sugar beet sequences, where maximum and minimum records of such trait were, respectively, obtained from maize growth after faba bean $\mathrm{S}_{6}$ and $\mathrm{S}_{1}$ sequences. Increased soil availability of $\mathrm{N}$ increased $\mathrm{N}$ uptake in $\mathrm{S}_{6}$, compared to the other crop sequences, resulting in the increase of LAI, light capture and conversion into photo assimilates translocated to the ears, hence, increased the number of fertile grains per ear. Compared to $S_{1}, S_{2}, S_{3}$, $\mathrm{S}_{4}$ and $\mathrm{S}_{5}$, increases in this trait for $\mathrm{S}_{6}$ crop sequences, reached 23.9, 19.6, 13.2, 7.3 and 3.6 grains, as an average of the two seasons. As indicated, the lowest grain number/ ear was obtained after sugar beet followed by fodder maize, and that might be explained by their higher soil $\mathrm{N}$ removal due to sugar beet longer growth duration and greater $\mathrm{N}$ depletion from the top soil by fodder maize. That was in agreement with the findings of Khalil et al. (2011) and Shaalan et al. (2014) who concluded that less $\mathrm{N}$ uptake by legume plants increased the $\mathrm{N}$ uptake by the following non legumes, enhancing photo assimilates production and translocation to plant different sinks and, in turn, enhancing maize doesn't produce spilekets fertilization and grains setting and number.

Ear grain weight in $\mathrm{S}_{6}$ sequences, despite its statistical equality with $\mathrm{S}_{5}$ sequence, was significantly higher than in the remaining other sequences. The heaviest grain weight/ ear, after faba bean, might be due to the beneficial effect of faba bean residues (higher organic matter soil content and $\mathrm{N}$ supply) on subsequent maize, in terms of increase in assimilate production and flux into maize ears to increase the ear grain weight (Gardner et al., 1985; Blair et al., 2006 and Egli, 2008). However, the lower response of maize to the effect of sugar beet and other faba bean sequences might be explained by the lower amounts of residual organic matter and $\mathrm{N}$ that decreased the rate of photosynthesis and, hence, the amount of dry matter accumulated into grains, thus, lowering ear grain weight of maize (Nawar, 2004 and Khalil et al., 2011).

Grain yield and 100-grain weight were significantly affected by cropping sequences in both seasons. Onehundred grain weight of maize after faba bean $\left(\mathrm{S}_{6}\right)$ was statistically equal to that of maize after sunflower, following faba bean $\left(\mathrm{S}_{5}\right)$ and was significantly superior to that in the remaining sequences (i.e., $\mathrm{S}_{1}, \mathrm{~S}_{2}, \mathrm{~S}_{3}$ and $\mathrm{S}_{4}$ ). That could be attributed to the more availability of $\mathrm{N}$ in $\mathrm{S}_{5}$ and $\mathrm{S}_{6}$ sequences, which led to the greater $\mathrm{N}$ uptake by maize plants, compared to the remaining crop sequences. The more $\mathrm{N}$ uptake, the greater assimilates production and translocation to ears, resulting in an increase of a single grain weight (Nawar, 2004, Khalil et al., 2011 and Shaalan et al., 2014). It should be noted that the same trend of significant variations were found among the preceding crops for grain yield in both seasons. The highest value for that trait was obtained from $\left(\mathrm{S}_{6}\right)$ in both seasons. Maize after faba bean produced $4.5,3.6,2.1,1.8$ and 0.7 ardabs/ fed, as an average of the two seasons, greater than grain yield with maize growing in $\mathrm{S}_{1}, \mathrm{~S}_{2}, \mathrm{~S}_{3}, \mathrm{~S}_{4}$ and $\mathrm{S}_{5}$ sequences, respectively.

Regarding, HI, data showed that this trait had the same trend of grain yield trait over the two seasons. Maximum and minimum records of such trait were obtained, consequently, from $\mathrm{S}_{6}$ and $\mathrm{S}_{1}$ sequences. Superiority of $\mathrm{HI}$ in $\mathrm{S}_{6}$ might be ascribed to higher increase in ear grain yield, compared to straw yield (data not presented). These results were in agreement with those of Sinclair and Gardner (1998) who found that increases in plant economic part, relative to uneconomic, increased maize HI.

In conclusion, improving soil physical structure and soil $\mathrm{N}$ and its organic matter, in faba sequences, were favorably reflected in maize higher grain yield and its attributes.

\section{B- Effect of nitrogen levels on maize traits:}

Mean values for maize traits, as influenced by $\mathrm{N}$ levels, are presented in Tables (2 and 3). Data indicated significant responses of all studied traits, except for plant and ear heights in addition to number of leaves/ plant, which were insignificantly increased with $\mathrm{N}$ level in a consistent course of change in both seasons.

Data analysis showed that the expansion of ear leaf area was significant in response to $\mathrm{N}$ level, where, the increase in such trait was in proportion to the supply of $\mathrm{N}$ level during the two seasons. When maize was supplied with $135 \mathrm{kgN} / \mathrm{fed}$, it produced wider ear leaf area by 23.4 and $63.7 \mathrm{~cm}^{-2}$, in 2013 , and 19.4 and 44.6 $\mathrm{cm}^{-2}$ in 2014 summer seasons, compared to 120 and 105 $\mathrm{kgN} /$ fed., respectively. Increasing $\mathrm{N}$ application level led to an increase in availability of soil $\mathrm{N}$ and its uptake by maize plants. That might be associated with the role of nitrogen in enhancement of leaf growth and expansion of maize leaves, especially, that for ear-leaf, as reported by Nawar (2004) and Khalil et al. (2011). 


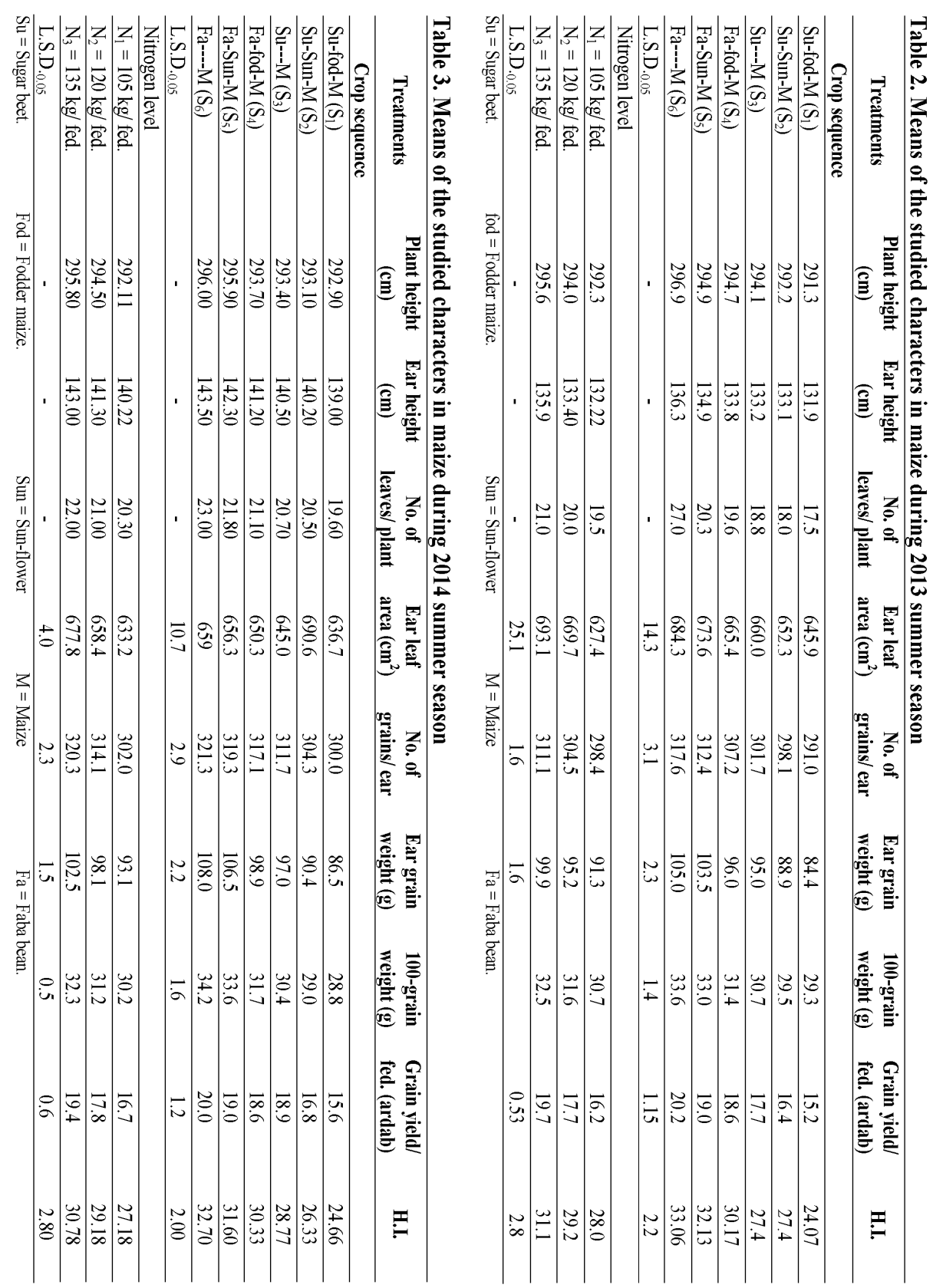




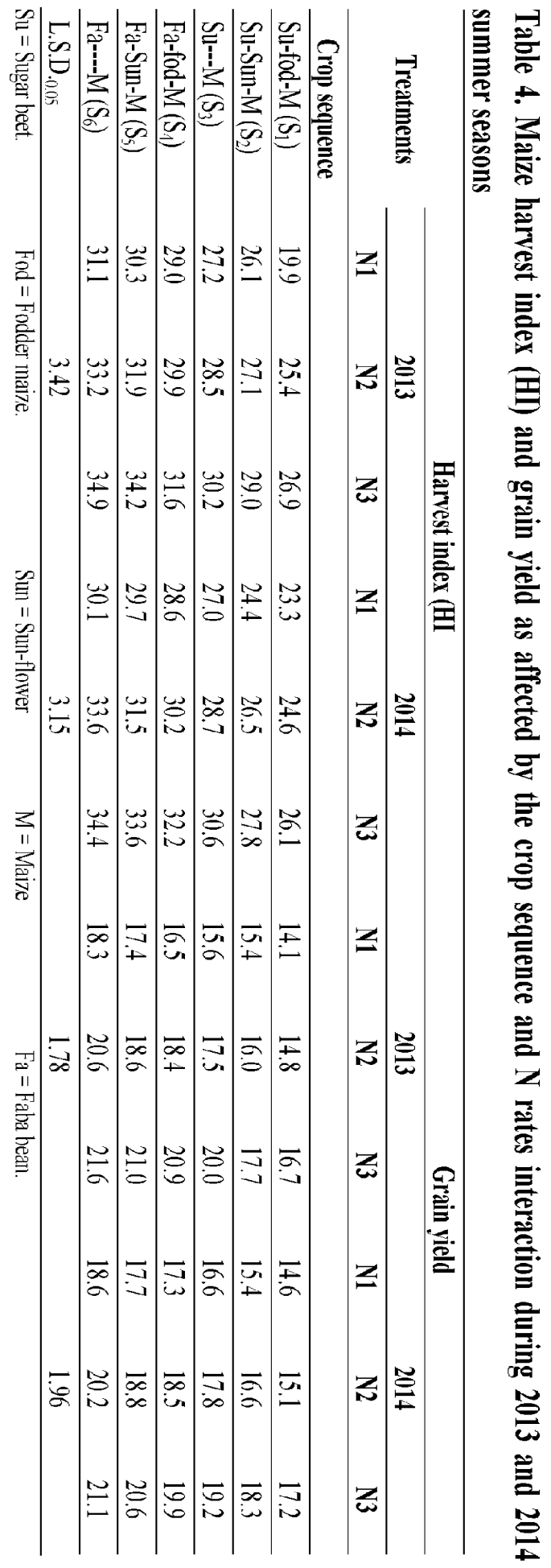


Table 5. $\mathbf{R}^{2}$ values for stepwise regression (forward)

\begin{tabular}{ll}
\hline Variable included & $\mathbf{R}^{2}$ \\
\hline Ear grain & 0.92 \\
\hline Ear grain +100 -grian weight & 0.96 \\
\hline Full model & 0.97 \\
\hline No other variable met the 0.10 significant level for entry into the model. &
\end{tabular}

Furthermore, variations in number of grains/ ear, as affected by $\mathrm{N}$ addition, were significant and had a similar trend to that of ear leaf area over the two seasons. Increasing the $\mathrm{N}$ level up to $135 \mathrm{~kg} / \mathrm{fed}$. produced the highest grain number/ ear, compared to the lowest $\mathrm{N}$ level of $105 \mathrm{~kg} /$ fed. In comparison with $\mathrm{N}_{1}$ and $\mathrm{N}_{2}$, the $\mathrm{N}_{3}$ level gave more number of grains/ ear that reached 12.0 and 6.4 grains, as an average of the two seasons, respectively. These results could be explained by the increase in spikelets fertility as influenced by an adequate supply of $\mathrm{N}$, which enhanced the photosynthetic capacity of the plant and provided higher amounts of photosynthates that are translocated to the fertilized ovaries to initiate grain information (Gardner et al., 1985, Uhart and Andrade, 1995 and Sibedv et al., 2006).

Concerning, ear grain weight, the highest grain weight/ ear was obtained by $\mathrm{N}_{3}$ application and reached 9.0 and $4.0 \mathrm{~g}$, as an average of the two seasons, greater than $\mathrm{N}_{1}$ an $\mathrm{N}_{2}$ levels, respectively. Increases in number of grains/ ear and individual grain weight might be responsible for increases in such trait. These results were in accordance with those Khalil et al. (2011) who found increases in ear grain weight in a direct proportion with the increase in $\mathrm{N}$ application rate. Similarly, Connor et al. (1993) and Nawar et al. (2009) attributed the increase in ear weight of maize plants to increases in grain number and photo assimilates translocation into ears as $\mathrm{N}$ rate increased.

One-hundred grain weight and grain yield/ fed. showed similar trends in their response to $\mathrm{N}$ supply over the two seasons. The values of both traits were increased in a direct proportion with the increase in $\mathrm{N}$ rate. Increases in 100-grain weight, compared to $\mathrm{N}_{1}$ as an average of the two seasons, were 1.0 and $2.0 \mathrm{~g}$ for $\mathrm{N}_{2}$ and $\mathrm{N}_{3}$, respectively. However, the higher application of $\mathrm{N}$ resulted in higher yields/ fed. That finding has been reported by several investigators, such as Hassan (1995) and EL-Ganbeehy et al. (2009).

Nitrogen application significantly affected HI. The maximum and minimum records of such trait were obtained from $\mathrm{N}_{3}$ and $\mathrm{N}_{1}$ levels, respectively. The $\mathrm{N}_{3}$ harvest index was, as an average of the two seasons, $31.0 \%$, compared to 27.6 and $29.3 \%$ for $\mathrm{N}_{1}$ and $\mathrm{N}_{2}$, respectively. The more response of $\mathrm{HI}$ to the higher $\mathrm{N}$ level might be attributed to greater uptake of nutrients and translocation to the economic yield, due to greater $\mathrm{N}$ uptake, which led to higher increases in grain yield/ ear than straw yield/ plant.

\section{C- $N$ level $\times$ crop sequence effects on maize traits:}

Data analysis (Table 4) show a significant response of grain yield and HI maize traits to crop sequence under $\mathrm{N}$ rates over the two seasons. The least values for such traits were obtained from $\mathrm{S}_{1}$ sequence with the application of $105 \mathrm{kgN} /$ fed. $\left(\mathrm{N}_{1}\right)$, whereas, the maximum records for both traits were obtained from sowing maize in $\mathrm{S}_{6}$ sequence with the highest $\mathrm{N}$ level of $135 \mathrm{~kg}$ / fed. Increasing $\mathrm{N}$ level up to $135 \mathrm{~kg}$ / fed., with the high amount of beneficial residues returned to the soil by faba bean, enhanced the uptake of $\mathrm{N}$ and other nutrients, increasing maize growth in terms of grain yield and its attributes, finally, increasing of HI, due to the relatively constant value of straw yield/ plant (data not presented). These results were in accordance with those of Shaalan et al. (2014) who reported that more residues returned to the soil with the high level of $\mathrm{N}$, applied to maize was associated with the greater $\mathrm{N}$ uptake, while resulted in the highest records of grain yield attributes and their associated grain yield.

Generally, data documented that relay cropping, as a manipulation of agriculture practice, to produce a third crop (triple cropping), in addition to the best choice of crop sequence, that includes a legume crop (faba bean) with an optimum $\mathrm{N}$ level supply, could help in raising land yield advantage attaining the required meaning from crop intensification.

Results of stepwise regression (forward) (Table 5) revealed that both 100-grain weight and number of grains/ ear explained about $96 \%$ of the variation in grain yield in both seasons, indicating the importance of those two characters in determining productivity of maize. Also, factors affecting those two characters, such as $\mathrm{N}$ fertilization may have an effect on grain yield production.

\section{REFERENCES}

Blair Nelly, R.D., A.R. Faulkner and P.R. Poulton (2006). Long-term management impacts soil C.N and physical fertility. Soil and Tillage Research, (91): 30-38.

Connor, D.J., A.J. Hall and V.O. Sadras (1993). Effect of nitrogen content on the photosynthetic characteristics of sunflower leaves. Aust. J. Plant Physiol. (20): 251- 263. 
Egli, D.B. (2008). Comparison of corn and soybean yields in the United States. historical trends and future prospects. Agron. J. (100) Suppl., 79-88.

EL-Ganbeehy, M.M., H.E. Khalil and A.S. Kamel (2009). Maize for grain and fodder maize under different seeding rates and N levels. Minufiya J. Agric. Res., (34): 661675.

EL-Sodany, M.E. and A.M. Abou-Elela (2010). Effect of preceding winter crops relay cropping, intercropping system and nitrogen fertilizer on soil physical and chemical properties. J. of Soil Science and Agriculture Engineering, (1): 273-298.

Fageria, N.K. (2009). Nitrogen. Pp 31- 90. In "The Use of Nutrients in Crop Plants" CRC press, Florida, USA.

Gardner, F.B.; R.B. Peacre and R.L. Nitchell (1985). Physiology of Crop Plants. Iwa State Univ. Press Ames, Iwa, USA.

Gomez, K.A. and A.A. Gomez (1984). Statistical Procedures for Agricultural Research $2^{\text {nd }}$ ed. John Wiley and Sons, New York, USA.

Hassan, A.A. (1995). Breeding for Increasing Productivity Potential and Tolerance to Environmental Stress. Pp. 4966. In "Physiological Basis of Genetic Improvement in Plants". Academic Library, Egypt (in Arabic).

Khalil, H.E.; A.I. Nawar, A.M. Abou-Elela, I.E. Mohammadein and M.E. EL-Sodany (2011). Response of maize to $\mathrm{N}$ fertilization and rotational crop sequences. Alex. J. Agric. Res., (54): 29- 39.

Khalil, H.E.; A.I. Nawar and A.S. Kamel (2004). Response of sunflower to multiseasonal crop sequences under different regimes of NPK fertilization. Alex. J. Agric. Res., (99): 13- 23.

Khalil, H.E.; S.Sh EL-Tabbakh; M.M. EL-Ganbeehy and S.E. Toaima (2000). Maize response to preceding winter crops and nitrogen fertilization levels. J. Agric. Sci. (26): 151161, Mansoura Univ., Egypt.

Nawar, A.I. (2004). Nitrogen requirements for maize cultivars after different winter crops. J. Adv. Agric. Res., (9): 607621.

Nawar, A.I., I.E. Mohammadein and H.E. Khalil (2009). Response of maize to $\mathrm{N}$ fertilization and rotational crop sequences. Alex. J. Agric. Res., (54): 29- 39.

Shaalan, A.M.; Nagwa R. Ahmed; Shams. Amr. S.A. and H.E. Khalil (2014). Rotational crop sequences and $\mathrm{N}$ fertilization levels effect on maize growth and productivity. Alex. Sci. Exch. J., (35): 154- 161.

Sibedi, K.D.; B.L. Ha and D.L. Smith (2006). Response of leafy and non-leafy maize hybrids to population densities and fertilizer nitrogen levels. Crop Sci., (46): 1860- 1869.

Sinclair, T.R. and E.P. Gardner (1998). Environment Limits to Plant Production. Pp. 63- 78. In "Principles of Ecology in Plant Production". CBA, New York, USA.

Uhart, S.A. and F.H. Andrade (1995). Nitrogen deficiency in maize. 1- Effects on crop growth, development, dry matter partitioning and kernel set. Crop Sci., (35): 1376- 1383.

Zamski, E. and A.A. Schoffer (1996). Photoassimilate Distribution in Plants and Crops. Source Sink Relationships-Marcel Dekker, Inc. 


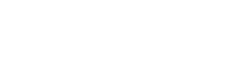

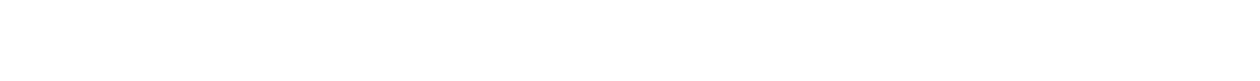

عسلم الين محمد إبراهيم، تامر إبراهيم اللسيد عبد الوهلب، على عيسى نوار، هسن للسيد خليل

لصفات محصول الحبوب/ فدان ودليل الحصاد في كلا

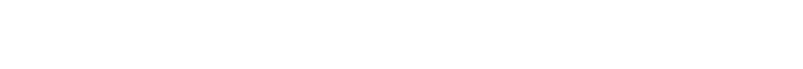

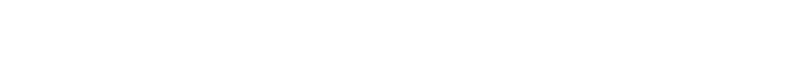

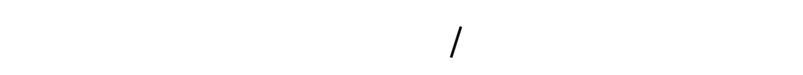

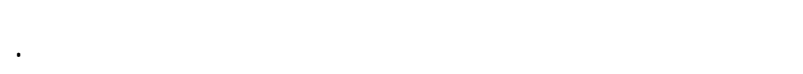

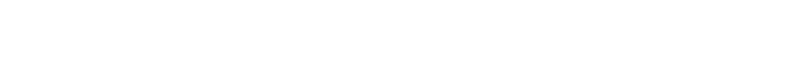

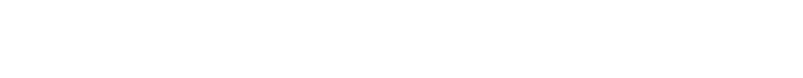
العلم. وكذك ألشارت بيانات تحليل الارتداد المتدرج

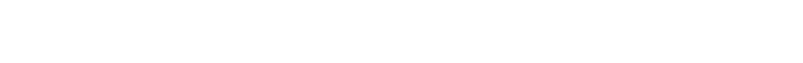
يعارل 97, · من الاختلافت فى كمية المحصول/ فدان.

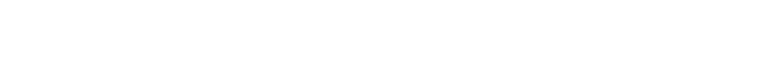

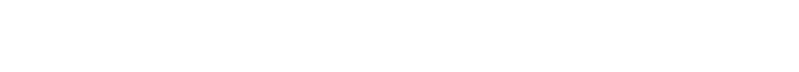
مكونات المحصول حيث فسرت 97\% من الاختلافت فـ

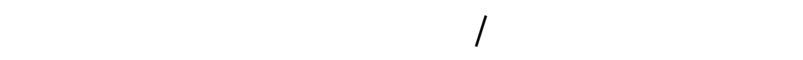

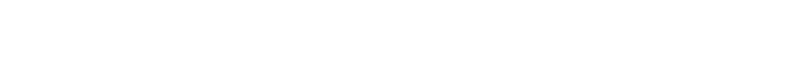

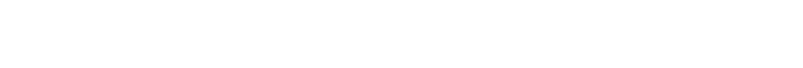
أيضاً على إنتلجية الفدان.
مُ درلمة إمبتجابة محصول الذرة اللشمية لمستة تعاقبلت

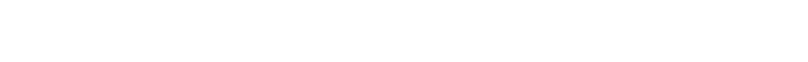

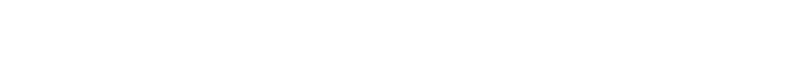

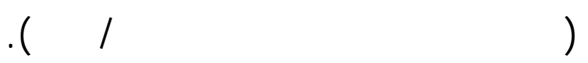

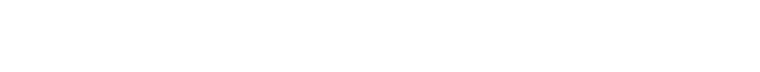

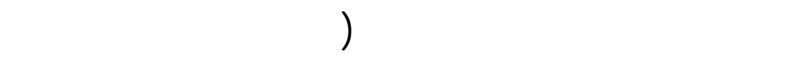
الحبة ووزن حبوب الكوز) بالإضافة إلى دليل الحصاد، حيث مم الحصول على أعلى وأقل القيم لهذه الصفالت عندما

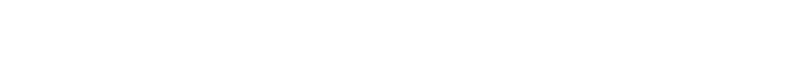

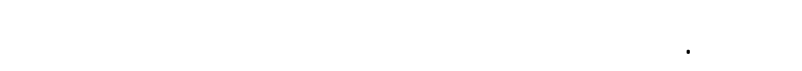
عله محصول الفول البلدى أعطت أعلى القيم لهذه الصفات مقارنة بزراعة الذرة اللشمية في تعاقبت بنجر اللسكر. كما أوضحت النتائح أيضاً أن للتسميد النيتروجيف تأثيرأ

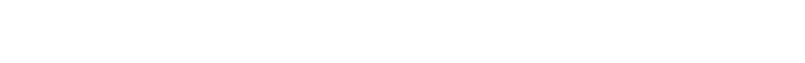

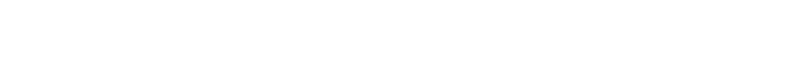
الصفلت عنما قم إضافة 0س ا كجم نيتروجين للفدان.

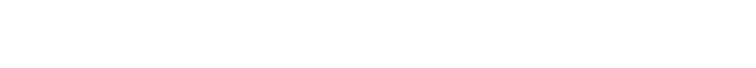
معنوياً بين المحاصيل السلقة ومستوى التسميد النيتروجيف لماتيف 